\title{
GEOPOLITICAL PROBLEMS OF UKRAINE-BELARUS BORDER REGION
}

\author{
Vladyslav MORGATSKYI \\ Ivan Franko National University of Lviv, Ukraine \\ vladkulykivka@ukr.net
}

\begin{abstract}
The article presents geopolitical peculiarities of Ukraine-Belarus border region in the latest historical dimension. Delimitation and demarcation of the interstate border, formation of appropriate infrastructure are also examined here. In the context of political and geographical aspects attention is focused on international relations between two countries and also on the processes of integration in Euro-Atlantic and Post-Soviet regions. Features of geopolitical impact of Russia are reviewed in the light of interstate relations in the triangle Russia-Ukraine-Belarus. Geopolitical doctrine of Yurii Lypa and ethnopolitical conception of Yatvingians are examined for using nowadays. The main steps of establishment of boarder troops in Belarus are described as well as military and technical cooperation with Ukraine. In the text are defined the trends of cross-border cooperation and are determined the geopolitical, social and geo-ecological threats for the border region in the context of national security of Ukraine.
\end{abstract}

Key words: Ukraine-Belarus border region, state border, delimitation and demarcation, political and geographical choices, cross-border relations, national security.

DOI: http://dx.doi.org/10.17721/2413-7154/2016.75.80-86

UDC: 911.3

\section{ГЕОПОЛІТИЧНІ ПРОБЛЕМИ УКРАЇНСЬКО-БІЛОРУСЬКОГО ПРИКОРДОННОГО РЕГІОНУ}

\author{
Владислав МОРГАЦЬКИЙ \\ Львівський начіональний університет імені Івана Франка \\ vladkulykivka@ukr.net
}

\begin{abstract}
Анотація: у статті розглянуто геополітичні особливості українсько-білоруського прикордонного регіону в новітньому історичному вимірі. Обумовлено проблеми делімітації та демаркації міждержавного кордону, формування відповідної інфраструктури. У політико-географічних аспектах сконцентровано увагу на міждержавних відносинах країн як на двосторонньому рівні, так і в інтеграційних процесах у євроатлантичному та пострадянському регіонах. Розглянуто особливості геополітичного впливу Росії крізь призму відносин у трикутнику Росія-Україна-Білорусь. Вивчено можливості використання геополітичної доктрини Юрія Липи та ятвязької етнополітичної концепції на сучасному етапі. Описано основні етапи формування прикордонних військ Республіки Білорусь, а також - військово-технічна співпраця з Україною. Визначено тенденції транскордонного співробітництва та схарактеризовано загрози геополітичного, соціального та геоекологічного характеру для прикордонного регіону в контексті національної безпеки України.

Ключові слова: українсько-білоруський прикордонний регіон, державний кордон, делімітація та демаркація, політикогеографічний вибір, транскордонне співробітництво, національна безпека.
\end{abstract}

DOI: http://dx.doi.org/10.17721/2413-7154/2016.75.80-86

УдК: 911.3

Українці та білоруси у своєму історичному розвиткові мають багато спільного. Довгий період перебування в одній державі ускладнив становлення міждержавних меж (надто - у роки існування Радянського Союзу), однак, поглибив процеси формування та функціонування прикордонного регіону. Українсько-білоруський кордон - це успадкований внутрішній кордон СРСР, який розмежовував території УРСР та БРСР. Стаття 5 Закону України «Про правонаступництво» визначає, що «державний кордон Союзу РСР, що відмежовує територію України від інших держав, та кордон між Українською РСР і Білоруською РСР... за станом на 16 липня 1990 року $є$ державним кордоном

(C) В. Моргацький
України» [10]. У Концепції Національної стратегіï транскордонного співробітництва в Україні прикордонний регіон трактується як «адміністративно-територіальна одиниця, що знаходиться на рівні, наступному після державного, i розташована безпосередньо вздовж державного кордону [8]. До цього прикордонного регіону від України входять північні та центральні райони Волинської, Рівненської, Житомирської, Київської та Чернігівської областей, а від Білорусі - південні адміністративні одиниці Брестської та Гомельської областей [18].

Дослідженнями особливостей формування та функціонування українсько-білоруського прикордонного регіону займались: географи С. Л. Рудницький, В. М. Кубійович, Ф. Д. Заставний, 
М. С. Дністрянський, Г. П. Підгрушний, О. М. Черевко, О. В. Ханова; економісти - В. С. Кравців, В. В. Засадко, Ю.О.Цибульська; історики - О.Д.Панько, С.А.Шаправський, В.І.Сергійчук, Т. В.Павлова; відомі громадські діячі - Ю.І.Липа, О.Г.Цадко та інші.

У статті використано методи теоретичного, історико-логічного та функціонально-системного аналізу.

Особливості політико-географічного формування та функціонування українськобілоруського прикордоння характеризуються такими проблемами:

- делімітація та демаркація кордону;

- формування пунктів пропуску, прикордонної інфраструктури та митної зони;

- політико-географічний вибір держав між євроатлантичним вектором та інтеграційними процесами на пострадянському просторі;

- розвиток транскордонного співробітництва;

- вплив світових економічних криз та російськоукраїнського військового конфлікту на розвиток міждержавних стосунків;

- геополітична, соціальна та геоекологічна безпеки в контексті національної безпеки України.

У 1993-1997 pp. проведено делімітацію державного кордону між досліджуваними країнами загальною протяжністю 1084,5 км. Основою топографо-геодезичних i картографічних робіт iз делімітації кордону стало прийняття українськобілоруською комісією 3 делімітації державного кордону рішення про переоформлення топографічних карт масштабу 1:10000 із розграфленням у системі координат 1963 року в систему координат 1942 року, а також виконання повного комплексу робіт із оновлення карт за матеріалами аерофотознімання. На лінії кордону українською стороною було оновлено 161 аркуш топографічних карт, а білоруською - 103. Лінію делімітації нано- сили на оновлені топографічні карти масштабу 1:10000. На них були позиціоновані точки поворотів та лінія державного кордону 3 відтіненнями. На основі карт створено Протокол-опис проходження лінії державного кордону між Україною та Республікою Білорусь [14].

Формування пунктів пропуску розпочато в 1992 році. До кінця десятиріччя відкрито 14 пунктів (двоє з яких - залізничні). На початку 2000-х мережа збільшилась ще на 8 пунктів пропуску. Останню хвилю зафіксовано у 2013 році, коли після ратифікації договору про демаркацію кордону відкрили ще п'ять пунктів перетину (зокрема, три залізничні). Тобто наразі мережа має 27 пунктів пропуску, 14 із яких - міжнародні, що найбільше відповідають сучасним стандартам i відрізняються більшою пропускною спроможністю. Вона досить розвинена як для нещільно заселеного поліського регіону, але слід звернути увагу на стан автомобільних доріг, які ведуть до міждержавних та місцевих пунктів пропуску, більшість із яких у незадовільному стані. Особливо це стосується доріг Рівненщини та частково Чернігівщини й Житомирщини. Основними автомагістралями $є$ міжнародні (Київ - Чернігів - Нові Яриловичі, Доманово - Ковель - Чернівці - Тереблече), регіональні (Чернігів - Городня Сеньківка, Луцьк - Любешів - Дольськ) та інші. Слід відмітити, що основні товарні потоки рухаються не в субмеридіональному напрямку, а в субширотному - магістралями, що зв’язують Україну й Білорусь із Польщею (Київ - Люблін, Гомель - Брест - Варшава), тому прикордонний регіон не відіграє настільки потужної ролі попри сформовану ще в радянський період транспортну мережу.

Головним документом, що регулював питання делімітації, а згодом - і демаркації кордону, був підписаний 18 липня 1997 року «Договір між Україною та Республікою Білорусь про державний кордон». Український парламент ратифікував його

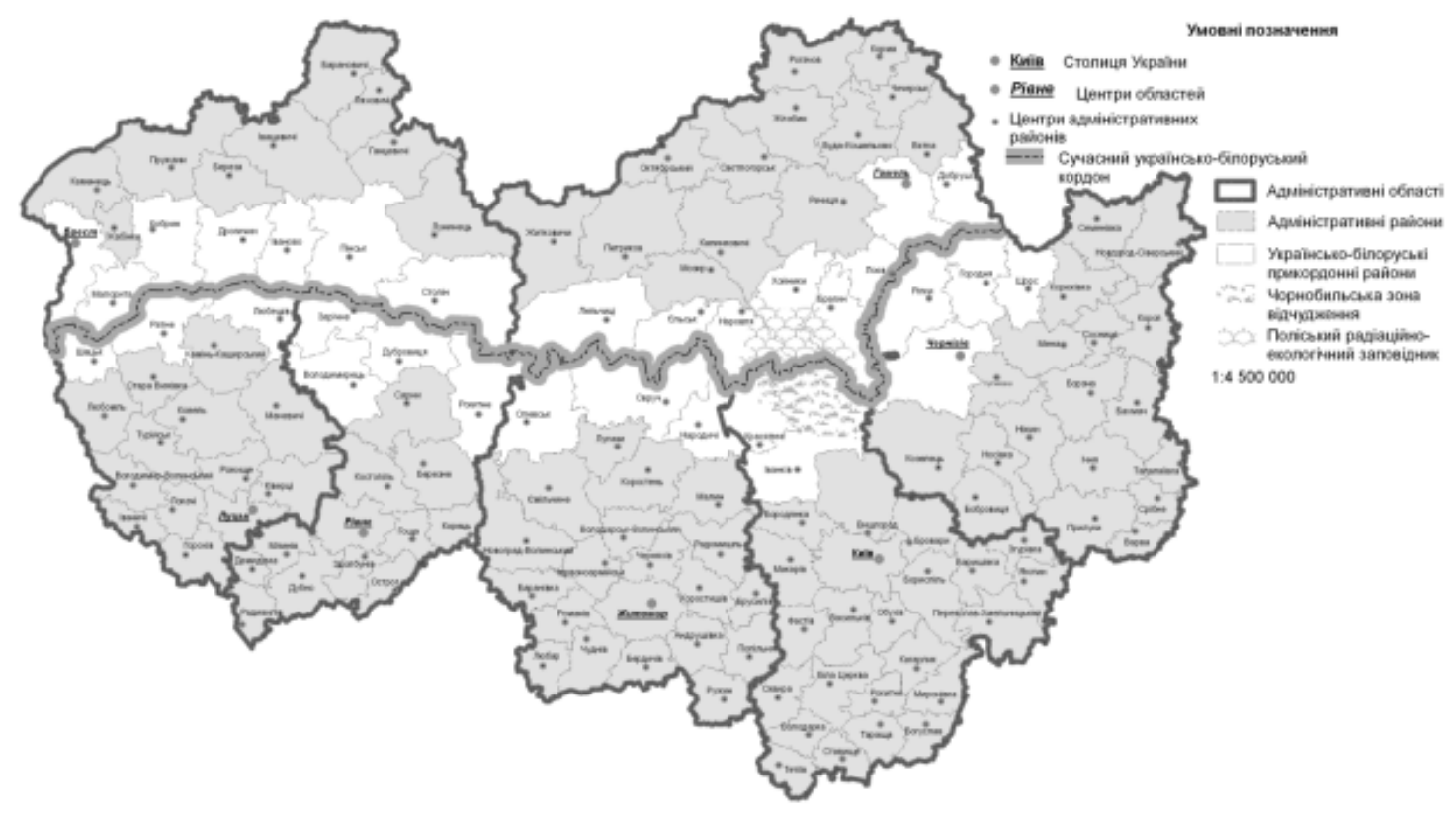

Рис. 1. Українсько-білоруський прикордонний регіон (за О. М. Черевко) 
через два місяці, а білоруський - лише в травні 2010 року [13]. Керівництво Білорусі пов'язує питання кордонів із проблемою боргу, що існує між країнами ще з часів розпаду СРСР (за випущену, але не відвантажену продукцію). Оцінка боргу обома сторонами не збігається. Вирішенню проблеми сприяли домовленості між В.А.Ющенком та О. Г. Лукашенком щодо зменшення цін на українські енергоносії в обмін на відмову від «політичного шантажу» [1; 361]. Якщо в Києві сумою заборгованості вважалися не більше 50 млн. дол. США, то в Мінську наполягали на 200 млн дол. США. У 2003 р. прем’єр-міністри держав підписали протокол, де сума боргу була зафіксована на рівні 134 млн. дол. США. Українська сторона досі не погоджується сплатити борг державним суб'єктам господарської діяльності Білорусі [5; 29-33].

I3 середини 2000-х мали місце проблеми захоплення українських земель, пов'язані зі зміною русла Дніпра, що давало змогу білорусам присвоїти досить великі ділянки (близько 660 га землі) на Чернігівщині. Від початку 2016 року громада села Ветли Волинської області протестує проти передачі Жирівського каналу до складу Білорусі й у квітні перекрила частину ділянки «Любешів - Дольськ», вимагаючи роз'яснень від органів влади. Існують думки, що канал потрібен жителям, щоб вимивати бурштин. Однак, місцеве населення акцентує увагу на екологічних наслідках, що можуть призвести до обміління системи з чотирьох озер, у т. ч. озера Білого, деградацію земель, а, окрім того, дасть захопити 50 га території. На ці проблеми має зважати міжнародна демаркаційна комісія, а найбільше галузеві спеціалісти, що проводять такі роботи на місцевості [2].

Період після програшу на виборах національнодемократичних сил у Білорусі внаслідок перемоги О. Г. Лукашенка та ствердження Л. Д. Кучмою курсу на багатовекторність зовнішньої політики України характеризувався стабілізацією міждержавних відносин, поступовим формуванням мережі пунктів пропуску, розвитком транскордонного співробітництва, зокрема, створенням єврорегіонів «Буг» (Брестська, Волинська області та Люблінське воєводство Польщі) та «Дніпро» (Чернігівська, Гомельська, Брянська області). Зовнішня політика Білорусі спрямована на інтеграцію в пострадянський простір, що демонструється підтримкою Ташкентського пакту в 1993 році, входженням до Союзної держави в 1997-ому та ЄврАзЕС у 2000-ому. Поступові конфедеративні зв'язки з Росією мали вирішальне значення в побудові українськобілоруських відносин, що не сприяло поглибленню співпраці в прикордонному регіоні [1, с.346-360]. У сучасному контексті південні землі Білорусі за певних умов можуть стати військовою загрозою.

Політичне напруження між державами спостерігалось і в часи Помаранчевої революції та Євромайдану, адже білоруську владу непокоїла можливість переходу революційних настроїв із ближнього зарубіжжя на терени країни. 3 активізацією взаємовідносин між Білоруссю та ЄС у
2008 році та світовою економічною кризою 2009го співпраця розширилась у рамках Східного партнерства, де Україна, по суті, виступала посередником. Значне збільшення міждержавного товарообігу та прямих іноземних інвестицій у прикордонний регіон почалося після підписання в жовтні 2011 року Угоди про зону вільної торгівлі в рамках СНД. Вона стала головним фактором торгових війн 2012 року. Характерною рисою у відносинах України та Білорусі було збільшення тимчасової трудової міграції українців до міст на будівництво та на сезонні роботи в колгоспи. У 2010-13 рр. економічні стосунки поглиблювались, але геополітичні зв'язки характеризувались перманентним прихованим напруженням, оскільки країни Митного Союзу трансформувались у нове Євразійське економічно-політичне об'єднання [5; C.14]. Свразійським банком проводились комплексні дослідження білорусько-російсько-українського прикордоння (БРУП), які мали посприяти забезпеченню геополітичних та геоекономічних інтересів Росії в прикордонних регіонах САС [12].

На сучасному етапі транскордонне співробітництво представлене кількома основними програмами - Програмою транскордонного співробітництва «Польща-Білорусь-Україна» на 2014-2020 роки в рамках політики добросусідства, Програмою територіального співробітництва країн Східного партнерства, а також «Транскордонною стратегією співробітництва Люблінського воєводства, Львівської, Волинської та Брестської областей на 2014-2020 роки».

Безпека державних кордонів $\epsilon$ пріоритетом національної політики України. Тут доцільно згадати ідеї «Чорноморської доктрини» Юрія Липи. Згідно 3 нею Білорусь - «ключ українського чорноморського склепіння», завданням якого $\epsilon$ «недопущення до спільного кордону між балтійським і фіно-уральським експанзійним осередком», тобто збереження цієї країни як своєрідної буферної зони, яке потребує налагодження 3 нею дружніх відносин. «...Найбільшим нонсенсом $€$ ті чи інші претензії до білорусинів за той чи інший повіт, невиразну лінію кордонів. У найглибшому інтересі України була й буде дуже чесна й дуже зичлива політика до білорусинів. Без Білоруси українське склепіння $\epsilon$ в небезпеці. 3 другого боку, при цілковитій незалежности невеликої Білоруси буде вона відтята від півдня й стане знаряддям сусідів зліва чи справа, а значить раною на карті України. Тим часом при зичливім співжитті - Білорусь може стати шоломом на голові України. Геополітично білоруські землі - це такі ж наддніпрянські землі, як і ціла середня Україна. Оборона північних земель України лежить на рівнинних межах Білоруси...» [11; С. 946-947]. Попри те, що праці 75 років, актуальність іiі не зменшилась.

Приймаючи до уваги Чорноморську геополітичну доктрину й окремо домовленості Союзної держави, міркуючи про національну безпеку України, важливо розуміти, що відповідно до «Договору між РФ і РБ про спільні зусилля 3 
охорони зовнішнього державного кордону Республіки Білорусь» Російська Федерація фактично перенесла свої прикордонні інтереси від адміністративного кордону Росії та Білорусі на кордони з Україною, Литвою, Латвією та Польщею. Вона створила оперативну групу прикордонних військ, де Білорусь має своїх представників у командуванні. Таке співробітництво можна використати для проведення інтервенції. I, попри завіряння Олександра Лукашенка про неможливість нападу, подібну загрозу зневажати не можна.

На сучасному етапі завершена робота по розгортанню стратегічного угрупування прикордонних військ із виходом на охорону державного кордону з Україною. Проведені заходи зі створення прикордонної інфраструктури, обладнання й оснащення пунктів пропуску технічними засобами. 31 січня 1998 року розпочали охорону Державного кордону заново сформовані з'єднання прикордонних військ на українському напрямі 19-й (Гомель) та 20-й (Пінськ) загони, вдосконалено роботу даного загону і в Мозирі. Це якісно нові за організаційно-штатною структурою, формами й засобами дій підрозділи, які існують без традиційної прив'язки до обладнаних рубежів інженерних споруд, КСП, парканів. У Лоєві (поруч із Чернігівщиною) базується група прикордонних катерів, яка виконує завдання по охороні ділянки кордону на річках Дніпро та Сож загальною довжиною близько 160 км. [14; С.57]. Таким чином, ще в 2001 році в стратегічному й оперативному плані в цілому була створена база для діяльності прикордонних військ, що здатна забезпечити виконання політичних, військових, економічних завдань у системі безпеки Республіки Білорусь як у мирний час, так і при загостренні військовополітичної ситуації. Тому важливо уникати ескалації конфліктів чи здійснення будь-яких провокацій.

Щодо військово-політичної співпраці, то наразі діє міжурядова українсько-білоруська комісія 3 питань воєнно-технічного співробітництва. Одним iз вдалих прикладів спільної роботи експерти називають протитанковий ракетний комплекс (ПТРК) «Скіф», утілений київським конструкторським бюро «Промінь» і мінською компанією «Пеленг». Триває розробка багатофункціонального ракетного комплексу (БФРК) Сапсан», який створили ДКБ «Південне» (м. Дніпро) та підприємства ВПК Білорусі, що забезпечують проект пристроями самонаведення. 12 лютого 2014 року український уряд у рамках Договору між Кабінетом Міністрів України та Радою міністрів Республіки Білорусь про виробничу й науковотехнічну кооперацію підприємств оборонної промисловості дозволив заводу «Радар» (Київ) здійснювати експорт товарів воєнного призначення до Білорусі [15].

Але такі позитивні тенденції не повинні відводити на другий план питання безпеки. У Білорусі діє радіолокаційна станція «Волга» у Ганцевичах (північний схід Брестської області), 43-ого вузол зв'язку ВМФ Росії (Вілейка), а також заплановано звести авіабазу в Бобруйську, спрямовану охороняти Союзну державу від сил НАТО. У силу євроатлантичної військово-політичної інтеграції України ці об’єкти можуть бути використані проти неї.

Не слід забувати про соичіальну безпеку прикордонних регіонів. Попри заборону мовлення російських пропагандистських мас-медій в Україні, телеканал «Беларусь - РТР», програми якого ідентичні 3 «Россия-1», досі транслюється в північних районах Волині, Рівненщини та частково Житомирщини. Старше покоління, сприймаючи російську пропаганду, збільшує рівень недовіри до української влади. Експерти вважають, що мітинги матерів у Ратнівському та Старовижівському районах Волині кінця липня 2014 року, які виступали за демобілізацію й перекривали рух до білоруського кордону, частково спричинені впливом цих 3MI [6]. Тобто проросійські медіа, за потреби, можуть маніпулювати населенням на білоруських телевізійних частотах. Імовірно, що УПЦ МП теж може бути використана російською владою в політичних цілях як у південних регіонах Білорусі, так і на північних в Україні.

Не менш важливою у формуванні геополітичної стабільності є геоекологічна безпека прикордонного регіону. Вона грунтується на впровадженні спільних стандартів експлуатації та оцінки антропогенного впливу на ландшафти. Однорідність фізикогеографічних умов Поліського ландшафтного краю сприяє формуванню транскордонних об'єктів природно-заповідного фонду, а при поглибленій співпраці та відповідному фінансуванні можливе створення транскордонної екологічної мережі. Гарним прикладом є спільний польсько-українськобілоруський біосферний резерват «Західне Полісся», де розробляються та втілюються спільні програми 3 охорони біологічного й ландшафтного різноманіття, сталого розвитку території, проведення тристоронніх зустрічей тощо. Для сталості міждержавних політичних відносин у геоекологічному плані повинні укладатись домовленості щодо подолання наслідків Чорнобильської катастрофи та збереження біорізноманіття, що сформувалось у менш антропогеннонавантаженому середовищі. Після підписання указу Президентом України «Про створення Чорнобильського радіаційно-екологічного біосферного заповідника» від 26 квітня 2016 року (під час його подальшого формування та створення відповідної інфраструктури) виникне потреба координації дій із Поліським радіаційно-екологічним заповідником, а в разі їх об'єднання заповідна територія стане однією 3 найбільших у світі (440 тисяч км²). Не менш важливою $є$ співпраця інших природно-заповідних територій по обидва боки кордону, а також координація дій із обслуговування дренажних систем та функціонування меліоративної системи в прикордонному регіоні. Є сенс розвивати екологічну мережу Полісся, користуючись комплексними дослідженнями спеціалістів Інституту ботаніки НАНУ [3], теоретичними надбаннями Інститутів географії 
НАНУ та Інституту природокористування НАН Республіки Білорусь [11].

Крім вище наведених прикладів, національна безпека повинна грунтуватись не тільки на існуванні неупереджених геополітичних ідей та доктрин, а й на нівелюванні псевдонаукових. Тут загрозою, за умови дестабілізації ситуації в українськобілоруському прикордонному регіоні, може виступити суспільно-культурне об'єднання «Поліське». Мова йде про поширювану ним етнополітичну концепцію державностіЗахідного Полісся-виділення західних поліщуків за мовною й культурною ознакою та позиціонування себе як відмінної від білорусів, українців та поляків етнічної групи. Метою об'єднання є визнання жителів цієї території - нащадків ятвягів - національною меншиною, а згодом - отримання автономії. Було навіть розроблено теоретичні основи окремої літературної мови [16]. Поліська розмежувальна лінія (ПРЛ), що по суті виступає мовною межею слов'ян і балтів, а в сучасних дослідженнях - українців та білорусів, мотивується передусім фактами та явищами живої мови, а також поліськими діалектизмами та балтизмами, особливо в топоніміці. Українство говірок Берестейщини по ПРЛ на півночі краю фіксується авторами більшості народознавчих i мовознавчих досліджень Східної Європи XIX-XX століть [4]. Подивившись на карту ятвязького племені (Рис.2), можемо чітко уявити нікчемні політичні амбіції очільників «Поліське».

Отже, розпад СРСР, здобуття Україною та Білоруссю незалежності перенесли народи цих держав у нові геополітичні реалії. Взаємовідносини щодо прикордоння відразу ж закріпили на вищому державному рівні, однак, через постійні напруження в процедурі делімітації та демаркації кордону, не дуже інтенсивний розвиток прикордонної інфраструктури, що не відповідає сучасним стандартам, прийняття Україною курсу на входження до європейських структур, а Білоруссю - на співпрацю з країнами Співдружності, органи влади стали менш зацікавленими в поглибленні транскордонного співробітництва в регіоні, ставлячи акцент на єврорегіони, створені $з$ країнами-сусідами (представницями $\mathrm{CC}$ ). Якщо зважити на значний спад економіки України та Білорусі, геостратегічні плани російської влади щодо України, несформовану чітку позицію Білорусі в українському питанні, відсутність пріоритетності прикордонного співробітництва в стратегіях розвитку областей досліджуваного регіону, то спрогнозувати активізацію взаємодії поки неможливо.

Для сталості розвитку українсько-білоруського кордону потрібно:

- повністю узгодити режим демаркаційних робіт обох сторін та ще раз переглянути наявні інформа-ційні та картографічні матеріали для унеможливлення будь-яких суперечок, діяти на основі підписаної Угоди між Урядами України та Білорусі про затвердження «Положення про демаркацію державного кордону між Україною та Республікою Білорусь» від 30 липня 2014 року;

- на основі двосторонніх зустрічей між представниками державних органів влади переглянути договірно-правову базу міждержавних відносин у контексті російсько-українського збройного конфлікту;

- рекомендувати місцевим адміністраціям включити в програми розвитку прикордонних областей досліджуваного регіону плани щодо розвитку транскордонного співробітництва як у рамках єврорегіонів, так і на міжобласному рівні

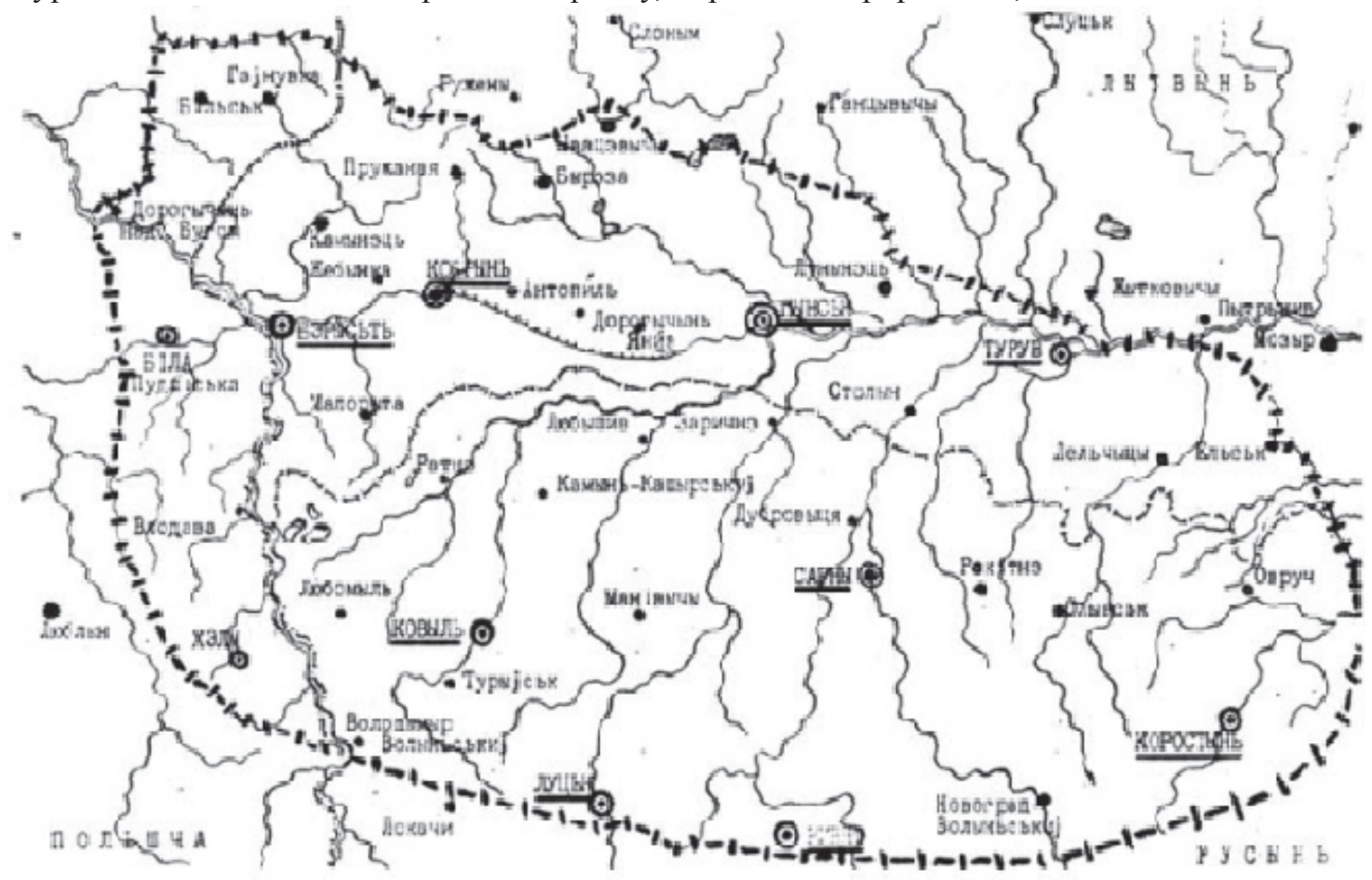

Рис. 1. Ятвязький етнолінгвістичний ареал (за Г.Антонюком) 
(на прикладі договору підписаного Волинською та Брестською областями), політичних контактів між їхніми очільниками;

- популяризувати в ЗМI та заохочувати інтелектуалів до формування та впровадження економічних, соціальних, екологічних та культурних програм, що фінансуються європейськими фондами в рамках Східного партнерства та єврорегіону «Буг», іншими державними програмами.

У рамках національної безпеки України в межах північних прикордонних областей потрібно:

- сформувати теоретичну базу функціонування прикордонних регіонів України в геополітичному вимірі на основі проведених досліджень транскордонних процесів та геополітичних тенденцій у нашій державі;

- посилити охорону українського кордону на півночі для військово-політичної безпеки;

- у межах фінансових можливостей удосконалювати інфраструктуру пунктів пропуску, митниць для зменшення нелегальної міграції та незаконного перевезення товарів;

- убезпечити свій інформаційний простір від упливу російської пропаганди, що поширюється через Білорусь, та реалізувати домовленість президентів про мовлення «UA:Перший» на території північного сусіда для альтернативного та більш об'єктивного інформування про суспільнополітичні процеси в нашій державі;

сприяти розширенню мережі об'єктів природно-заповідного фонду Поліського регіону 3 перспективою формування єдиної екологічної мережі, у тому числі й транскордонної, для підвищення геоекологічної безпеки;

- узгодити на політичному рівні подальші перспективи ліквідації наслідків Чорнобильської катастрофи, нівелювавши ті незгоди, що з'явилися за президенства В.Ф.Януковича, та сприяти формуванню міжнародного еколого-радіаційного заповідника.

\section{References:}

1. Vdovenko S.M. Ukraïna-Bìlorus': vzaêmovidnosini na perehrestâh peremìn [Ukraine-Belarus: relations at the crossroads of change]. Chernihiv, 2010, 448 p. (In Ukrainian).

2. Gogodza D. Podìl mež dovìv do mežì: čomu demarkaciâ kordonu u Vetlah lâkaê mìscevih [Drawing the boundaries has pushed to the limit: why the border demarcation in Vetly scares the locals]. First Information Agency "Volhynian News". Access mode: http://www.volynnews.com/news/society/-podil-mezh-doviv-do-mezhi-chomudemarkatsiia-kordonu-u-vetlakh-liakaye-mists/ (In Ukrainian).

3. Live Ukraine: fortnightly newsletter. UkrUNEPKOM. Ed.: Shelyag-Sosonko. Kyiv, 1998, N. 11-12, pp. 3-4. (In Ukrainian).

4. Leonûk V. Polìs'ka rozmežuval'na lìniâ [Polesian dividing line]. Nad Bugom ì Narvô̂u [Over the Buh and Narva]. Access mode: http://www.haidamaka.org.ua/0018.html (In Ukrainian).

5. Maksak G., Určak D. Sotrudničestvo Respubliki Belarus' $i$ Ukrainy v novyh geopolitičeskih usloviâh [Cooperation of the Republic of Belarus and Ukraine in new geopolitical conditions]. Access mode: http://library.fes. de/pdf-files/bueros/ukraine/11006.pdf. (In Russian).

6. Materì ta družini perekrili mobilizovanih volinân perekrili trasu v Ratnomu [Mothers and wives of mobilized Volhinians blocked the road in Ratne]. Television centre "Kovel". Access mode: http://www.kovel.tv/suspilstvo/materita-druzhyny-mobilizovanyh-volynjan-perekryly-trasu-v-ratnomu.html (In Ukrainian).

7. Nedokus İ. Problemi formuvannâ ì funkcìonuvannâ ukraïns'ko-bìlorus'kogo kordonu [Problems of formation and functioning of the Ukrainian-Belarusian border]. Proceedings of international scientific-practical Internet-conference "Modern Ukrainian-Belarusian relations: political, economic and socio-humanitarian aspects". (In Ukrainian).

8. Nêmec' K.A., Kulêšova G.O. Metodologičnì aspekti doslidžennâ transkordonnogo spìvrobitnictva regìonu (na prikladì Harkivs'koï oblastì) [Methodological aspects of cross-border cooperation in the region (on the example of Kharkiv Region)]. Visnik Harkìvs'kogo nacional'nogo universitetu imenì V. N. Karazina: Geologîa - Geografîa Ekologiâ [Bulletin of Kharkiv National University: Geology - Geography - Ecology"], 2008, Vol. 804, pp. 202-206. (In Ukrainian).

9. Novitnâ ukraïns'ka suspil'na geografîa. Hrestomatîa [Modern Ukrainian human geography: Collection of text]. Ed.: O. Šablij. Lviv, 2007, 1008 p. (In Ukrainian).

10. Pol'ovij T.Ê. Ukraïna - Bìlorus': osoblivostì mìžderžavnogo dìalogu na sučasnomu etapì [Ukraine - Belarus: specifics of inter-state dialogue at the present stage]. Visnik Dnipropetrovs'kogo universitetu. Seriâ: Filosofiâ. Sociologîa. Politologîa [Bulletin of Dnipropetrovsk University. Series: Philosophy. Sociology. Political Science], 2015, N. 1, pp. 160-168. (In Ukrainian).

11. Prigraničnoe sotrudničestvo regionov Rossii, Belarusi i Ukrainy [Cross-border cooperation of Russian, Belarussian, and Ukrainian regions]. Integration Research Centre of Eurasian Development Bank, 2013, 100 p. (In Russian).

12. Problemy prirodopol'zovaniâ v transgraničnom regione Belorusskogo i Ukrainskogo Poles'â [Natural management issues in trans-border region of Belorussian and Ukrainian Polesia]. Eds.: V. A. Palienko, V. S. Homič, L. Û. Sorokina. Kyiv, 2013, 290 p. (In Russian).

13. Sanžarevs'kij O. İ. Prikordonnì vijjs'ka Respubliki Bìlorus' v sistemì zabezpečennâ ìnnovacijnoï bezpeki na rubežì XX-XXI st. (za materìalami zovnišn'opolitičnih arhìvì Ukraïni ta Rosiii) [Border troops of the Republic of 
Belarus in the provision of innovative safety at the turn of XX-XXI centuries (using the materials of foreign policy archives of Russia and Ukraine]. Proceedings of international scientific-practical Internet-conference "Modern Ukrainian-Belarusian relations: political, economic and socio-humanitarian aspects". (In Ukrainian).

14. Sossa R.M. Kartografičnij aspekt doslìdžennâ admìnìstrativno-teritorìal'nogo ustroû Ukraïni [Study of the administrative-territorial division of Ukraine: cartographic aspect]. Regional'na istoriâ Ukraïni [Regional history of Ukraine] (Ed.: V. Smolij, Â. Vermenič), 2014, Vol. 8, 252 p. (In Ukrainian).

15. Ukraina i Belarus' razvivaût voenno-tehničeskoe sotrudničestvo [Ukraine and Belarus are developing military-technical cooperation]. Access mode: http://vlasti.net/news/187175. (In Russian).

16. The official website of the State Border Service of Ukraine. List of existing checkpoints across the state border and control points on the border with the Republic of Belarus. Access mode: http://dpsu.gov.ua/ua/static_page/52.htm ((In Russian).

17. Capko O. Poles'e i opyt nacional'nogo konstruirovaniâ [Polesie and the experience of national design]. Časopis palityčnyh dasledavannâu "Palityčnaâ sfera". Gistoryâ ì nacyâ [Bulletin of political studies "Political Realm". History and nation]. N. 24 (1), 2016. (In Russian).

18. Čerevko O.M. Ukraïns'ko-bìlorus'kij kordon: osoblivostì formuvannâ v XIX - XIX st. [The UkrainianBelarusian border: the specificity of formation in the XIX - XIX centuries]. Ekonomichna ta sotsialna geografiya, 2012, Vol. 64, pp. 245-252.Belarus in the provision of innovative safety at the turn of XX-XXI centuries (using the materials of foreign policy archives of Russia and Ukraine]. Proceedings of international scientific-practical Internetconference "Modern Ukrainian-Belarusian relations: political, economic and socio-humanitarian aspects". (In Ukrainian). 